\title{
Climate Based Coconut Yield Analysis in Chanrayapatna Taluk of Hassan District of Karnataka, India
}

\author{
Shripad Vishweshwar ${ }^{1 *}$, Shankar Meti, B.V. Champa and M. Nagaraja \\ University of Horticultural Sciences, Bagalkot, India \\ *Corresponding author
}

\section{A B S T R A C T}

Coconut has a prolonged reproductive phase of 44 months from the initiation of the inflorescence primordium to full maturity of the nuts. Weather affects all stages of the long development cycle and thus there is likely to be extended predictability based on climate variability. An attempt is being made to relate the coconut sample survey data of Coconut

Keywords

Coconut, Yield model, Future climate, Nut stages

Article Info

Accepted:

26 June 2019

Available Online:

10 July 2019 Development Board with climate data of Chanrayapatna taluk of Hassan district. Mean nut yield per palm, per year in the Chanrayapatna taluk was 83.3. Among the villages, Baldare recorded significantly lower nut yield (78.1) followed by Gulsinda (79.2) and Janivar (101.4). Annual rainfall during 2011, 2012 and 2016 was below normal compared to other years. Correlation of monthly nut yield/palm with rainfall showed a significant positive correlation with previous three to four years rainfall. Rainfall during 2013 and 2014 was comparatively better resulting in significantly higher nut yield during 2016 compared to 2014. Among the different stages, primordium initiation stage and ovary development stages were more strongly and significantly influenced by the weather parameters particularly temperature and contributed significantly to weather based regression model. Future climate of Chanrayapatna showed increase in annual rainfall mainly during September and October but decline during November/December. Maximum and minimum temperature showed increase by $1-1.4^{0} \mathrm{C}$ which may increase the evaporative demand resulting in moisture stress thus highlighting the importance of rain water harvesting to take advantage of increased rainfall under future climatic condition.

\section{Introduction}

The Coconut (Cocos nucifera) is a benevolent tree, a nature's gift to mankind and is an important source of earning livelihood to the people of coconut growing states. India ranks third in world coconut production and in recent times become the largest producer of coconut with the production of 22.17 billion nuts from about 2.09 m.ha plantations.
Coconut is the second largest and important horticultural crop of the Karnataka state, occupying 31 per cent of the total area under horticultural crop. The total area under coconut in the state is around 4.33 lakh hectares and the annual production of coconut is 303.6 million nuts. Tumkur followed by Hassan are the largest coconut producing district in Karnataka. The coconut is a perennial crop and it has a prolonged 
reproductive phase of 44 months from the initiation of the inflorescence primordium to full maturity of the nuts. The pre-fertilization phase from the initiation of the flower primordium to emergence accounts for 32 months. Weather affects all stages of the long development cycle extending to 44 months and thus there is likely to be extended predictability based on climate variability. Hence Coconut Development Board is undertaking annual production estimation survey in 31 major coconut growing districts of Kerala and Karnataka since 2013 to get advance estimate of coconut production. For a given farm, when other external factors are non-limiting; rainfall, temperature and relative humidity $(\mathrm{RH})$ during February, June, July, September and December in the year prior to the harvest are the major factors that influence the yield (Peiris and Thattil, 1998). Location specific predictive models to predict annual coconut yield have been developed using climatic variables alone (e.g. Nambiar et al., 1969; Reynolds, 1979; Peiris et al., 1995; Peiris and Thattil, 1998). Rainfall is the principal climatic variable that affects nut production (Peiris and Thattil, 1998). Karnataka state is experiencing drought consecutively from 2014. Arasikere taluk of Hassan district is experiencing deficit rainfall frequently coupled with decline in ground water level. Advance knowledge of coconut production at national and regional scales is useful for planning within the industry and in this direction attempts were being made earlier to predict coconut production using climate data such as rainfall by Abeyawardena as early as 1968 (Abeyawardena, 1968) and later by Peiris et al., (2008) in Sri Lanka. Similarly in India also attempts were made using climatic parameters (Krishna Kumar, 2011). Weather based coconut forecast model for Kerala was developed by Krishna Kumar (2011) and there is a need to develop such model for coconut growing areas of Karnataka and hence an attempt is being made to relate the coconut sample survey data of Coconut Development Board with climate data of Chanrayapatna taluk of Hassan district.

\section{Materials and Methods}

The yield forecasting of coconut assumes importance for framing any policy with respect to production, processing, marketing and pricing of coconut. In this connection, a field survey of Chanrayapatna taluk of Hassan district was entrusted by the Coconut Development Board, Ministry of Agriculture, Government of India, to UHS, Bagalkot.

\section{Study area}

For the present study Chanrayapatna taluk of Hassan district $\left(76.3^{0}-76.6^{0} \mathrm{E}, 12.8^{0}-13.2^{0} \mathrm{E}\right)$ was selected (Fig. 1). Hassan is a major coconut growing district in Karnataka state. It is divided into 8 taluks, 38 hoblies and 2369 villages.

Fig.1

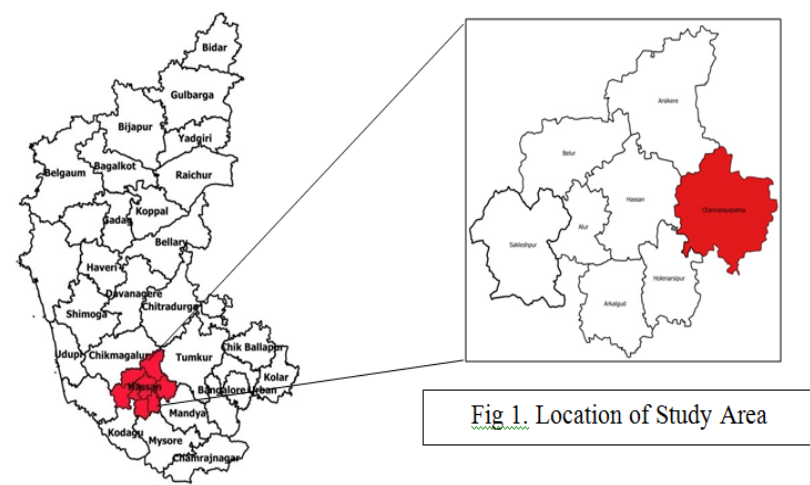

Sampling Frame

\section{Sampling frame}

The multistage random sampling technique was used to collect the required data from the required number of sample holdings for the purpose of estimating the coconut production in the district. 
In the first stage, leading taluk viz., Chanrayapatna was selected for the purpose of elucidating the information on coconut production as the share of this taluk in the district coconut area was 38.12 per cent. In the second stage, three panchayats were selected. The details of panchayath selected for the study in sample taluks are presented in Table 1. Then the 80 number of sample holdings in each of the selected panchayath was finalized randomly. Totally 800 palms from 80 holdings were selected for collection of the nut yield data for 2014 to 2017 using the standardized schedule provided by the Coconut Development Board through personal interview method by the Field Investigators appointed for the survey work with the help of climbers. Recorded the geographical location of the holdings using hand held GPS.

Each year collected number of nuts of different ages (3 to 9 months) from 10 palms from each holdings with the help of trained tree climbers during the month of December. Hobliwise weekly weather data (rainfall, temperature and $\mathrm{RH}$ ) were collected for 20102017 period from Karnataka State Natural Disaster and Management Cell (KSNDMC), Bengaluru (KSNDMC, 2018). Mean nut yield per palm per year was estimated for Chanrayapatna taluk and analyzed the significance of variation among the village and years. Using the temperature and $\mathrm{RH}$ data, monthly ET and vapor pressure deficit was estimated by following standard procedure. Monthly nut yield data was correlated with weather data during the five selected nut development stages viz. primordial initiation, formation of branches, spathe emergence, ovary differentiation and button size stage and developed predictive linear regression model for Chanrayapatna taluk. Downloaded the current (1950-2000) and future monthly climate (2100AD) data of maximum, minimum and rainfall from DIVA
GIS website (http://www.diva-gis.org/climate) and extracted for Chanrayapatna taluk using the GPS readings of sampled holdings. Future climate projection was based on WC_CCM3 model.

\section{Results and Discussion}

\section{Nut yield variation}

Mean nut yield per palm, per year in the Chanrayapatna taluk was 83.3 with inter annual mean nut yield among different villages showed variation with significantly lowest in 2014 (35.8 nuts/palm) followed by 2017 (96.7) and 2016 (97.5) and significantly highest in 2015 (103.2 nuts/palm) (Table 2). Among the villages, Baldare (78.1) and Gulsinda (79.2) recorded significantly lower nut yield followed by Janivar (101.4).

The coconut palm produces mature bunch which grows through a cycle of development lasting for many months before it is ready for harvest. These periods as well as certain period prior to this are very sensitive to major climatic factors such as rainfall, solar radiation, atmospheric relative humidity, etc. The effect of weather is usually reflected on the yields. The yield fluctuation between years is very complex. When nutrients are non-limiting, the yield variation is controlled mainly by the distribution of climatic variables. Yield of the coconut can vary within the district, due to variation in the climatic factors. Mean maximum and minimum temperature during 2010-2017 was 30.1 and $18.7^{\circ} \mathrm{C}$ respectively with average annual rainfall of $771.1 \mathrm{~mm}$. Annual rainfall during 2011, 2012 and 2016 was below normal compared to other years (Fig. 2). Correlation of monthly nut yield/palm with rainfall showed a significant positive correlation with previous three to four years rainfall (Table 3). 
In view of the long duration (44 months) between the primordium initiations to nut maturity, the occurrence of dry spell or wet spell in any season/year would affect the yield for the subsequent three to four years. In Arasikere also rainfall during consecutive two years 2010 and 2011 was low, as a result nut yield during the year 2014 was significantly low (Fig. 1). Rainfall during 2013 and 2014 was comparatively better resulting in significantly higher nut yield during 2016 compared to 2014. Similarly Kumar et al., (2007) reported that longer dry spell affects the nut yield for next four years to follow with stronger impact on fourth year, irrespective of the total rainfall. Rajagopal et al., (1996) also observed that the nut production under rainfed condition is influenced significantly by the length of dry spells at critical stages and the dry spell during the primordium, ovary development and button size is crucial for the production of nut yield.

\section{Weather vs. Nut development stage}

Monthly nut yield/palm during different year showed significant correlation with weather data during their corresponding nut development stages (Table 4). Among the different stages, primordium initiation stage and ovary development stages were more strongly and significantly influenced by the weather parameters during all the years. The primordium of the inflorescence is reported to develop in the leaf axils about 32 months before the opening of the inflorescence and seasonal conditions during these development stages spanning 32 months do affect the nut yield (Krishna Kumar, 2011). Rainfall and temperature during different nut development stages of each year monthly nut yield is depicted in Figure 3. Primordium (P) of the nuts which came to

Table 4 shows correlation of nut yield/palm with weather parameters at different stages harvest in 2014 and were initiated during May-Nov 2010 and coincided with good rainfall, but branch initiation $(\mathrm{Br})$, ovary development $(\mathrm{O})$, spathe emergence $(\mathrm{S})$ and button (B) stages experienced low rainfall (Fig. 3a). Because of successive low rainfall year of 2011-2013, nut development stages experienced stress resulting in low nut yield. This is clearly reflected in nut yield showing significant positive correlation with previous 2-3 years rainfall (Table 3 ).

Similarly nut yield showed significant negative correlation with $\mathrm{T}_{\max }(-0.82)$, ET ($0.76)$ and VPD (-0.84) and positively with rainfall (0.83) during spadix emergence (Table 4). However all the development stages of nuts which came to harvest during 2015 and 2016 experienced better rainfall and other climate parameters compared to 2014, as a result there was an improvement in nut yield during these two years (Fig. $3 b$ and c). It is interesting to note that even though the 2016 year annual rainfall was low, but the nut yield was better, because all the nut development stages experienced better rainfall and temperature. Effect of low rainfall experienced during 2016 was observed on 2017 nut yield (Fig. 3d). Button nut development stages of 2017 nuts coincided with 2016 low summer and monsoon rainfall and same thing is reflected in significant positive correlation of 2017 nut yield with 2016 rainfall (0.75) (Table 3$).$

Similarly Nambiar et al., (1969) identified three distinct stages of nut development with active growth period coinciding with 3-7 months after fertilization and any weather aberration during this period will adversely affect the rate of growth and final size of the nut and copra content. Among the months, nut production during May to July in all the years was high compared to winter months January and February. The result was in agreement with Rao (1988) and Rao et al., (1993). 
Table.1 Details of sampling

\begin{tabular}{|l|l|l|c|c|}
\hline Taluk & $\begin{array}{l}\text { Gram } \\
\text { Panchayath }\end{array}$ & Sample Villages & $\begin{array}{c}\text { No. of } \\
\text { Holdings }\end{array}$ & $\begin{array}{c}\text { No. of } \\
\text { Palms }\end{array}$ \\
\hline Chanray \\
apatna & 1.Baladere & Hirehalli and vagarahalli & 30 & $\mathbf{3 0 0}$ \\
\cline { 2 - 5 } & 2.Gulasinda & Kalasinda & 30 & $\mathbf{3 0 0}$ \\
\cline { 2 - 5 } & 3.Janivara & Gaddebindenahalli & 20 & $\mathbf{3 0 0}$ \\
\hline & & Total & $\mathbf{8 0}$ & $\mathbf{9 0 0}$ \\
\hline
\end{tabular}

Table.2 Village wise nut yield per palm per year for 2014-2017

\begin{tabular}{|c|c|c|c|c|c|c|c|}
\hline Taluk & Village & $\mathbf{2 0 1 4}$ & $\mathbf{2 0 1 5}$ & $\mathbf{2 0 1 6}$ & $\mathbf{2 0 1 7}$ & Mean & SE \\
\hline C. Patna & Baldare & 30.8 & 97.6 & 88.2 & 95.9 & $78.1^{\mathrm{a}}$ & 2.92 \\
\cline { 2 - 8 } & Gulsinda & 34.4 & 101.9 & 78.1 & 102.5 & $79.2^{\mathrm{a}}$ & 2.85 \\
\cline { 2 - 8 } & Janivar & 48.2 & 116.3 & 154.4 & 86.7 & $101.4^{\mathrm{b}}$ & 4.02 \\
\cline { 2 - 8 } & Mean & $\mathbf{3 5 . 8}$ & $\mathbf{1 0 3 . 2}$ & $\mathbf{9 7 . 5}$ & $\mathbf{9 6 . 7}$ & $\mathbf{8 3 . 3}$ & $\mathbf{1 . 7 3}$ \\
\hline
\end{tabular}

Table 3 Correlation of nut yield with different years rainfall

\begin{tabular}{|l|c|c|c|c|}
\hline & $\mathbf{2 0 1 4}$ & $\mathbf{2 0 1 5}$ & $\mathbf{2 0 1 6}$ & $\mathbf{2 0 1 7}$ \\
\hline RF2010 & -0.52 & $\mathbf{- 0 . 8 1}$ & -0.52 & $\mathbf{- 0 . 7 7}$ \\
\hline RF2011 & $\mathbf{0 . 6 6}$ & $\mathbf{0 . 7 8}$ & $\mathbf{0 . 8 1}$ & 0.59 \\
\hline RF2012 & -0.36 & -0.63 & -0.39 & -0.62 \\
\hline RF2013 & $\mathbf{0 . 6 7}$ & $\mathbf{0 . 9 2}$ & 0.61 & $\mathbf{0 . 8 4}$ \\
\hline RF2014 & -0.10 & -0.52 & 0.16 & $\mathbf{- 0 . 7 2}$ \\
\hline RF2015 & 0.00 & 0.32 & -0.50 & 0.58 \\
\hline RF2016 & 0.12 & 0.51 & -0.37 & $\mathbf{0 . 7 5}$ \\
\hline
\end{tabular}

* significant at 0.05

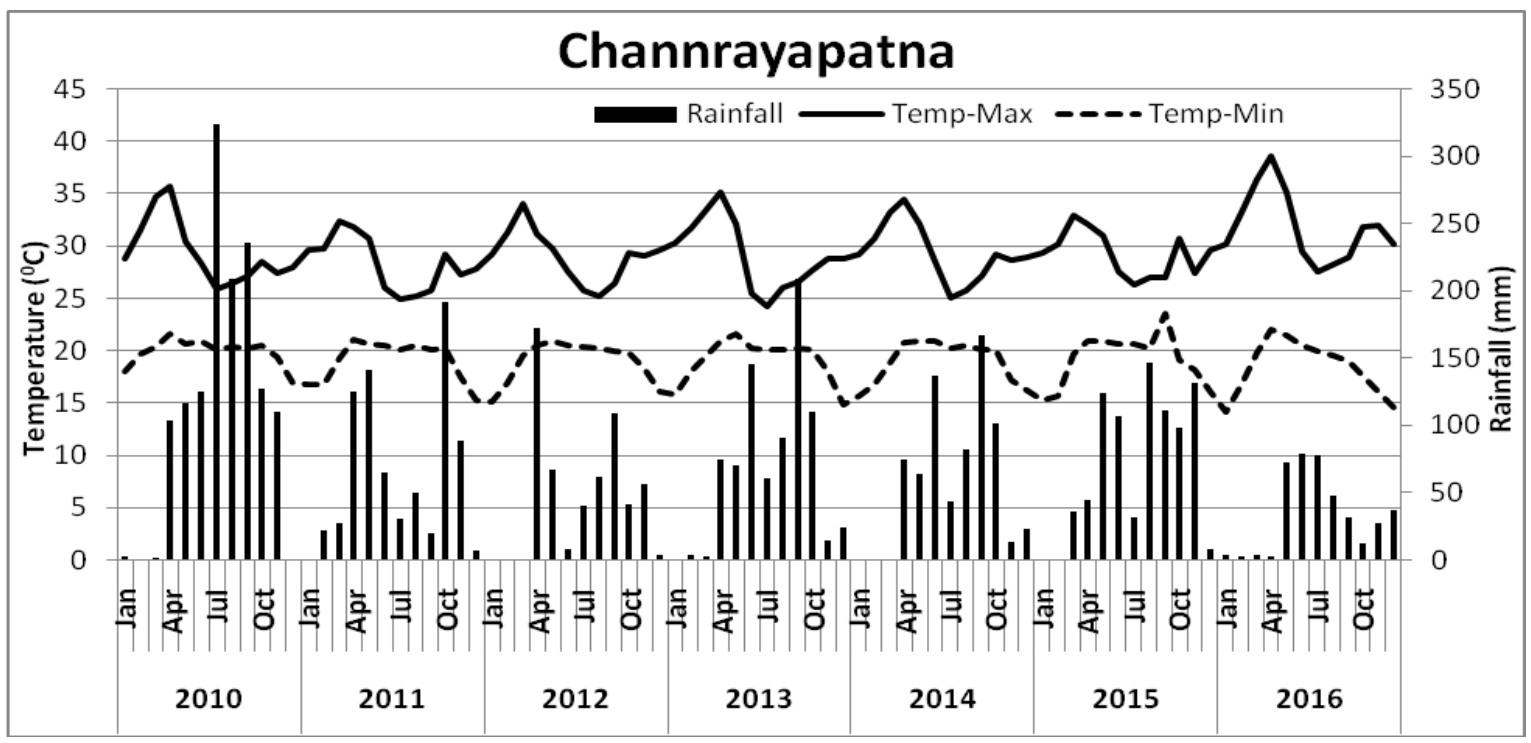

Fig.2 Weather at Chanrayapatna taluk during 2010-2016 
Table.4 Correlation of nut yield/palm with weather parameters at different stages

\begin{tabular}{|c|c|c|c|c|c|}
\hline \multirow[t]{2}{*}{ Stage } & \multirow{2}{*}{$\begin{array}{c}\text { Weather } \\
\text { parameter }\end{array}$} & \multicolumn{4}{|c|}{ Channarayapatna } \\
\hline & & 2014 & 2015 & 2016 & 2017 \\
\hline \multirow[t]{5}{*}{ Primordium } & Tmin & -0.48 & -0.18 & -0.52 & $-0.80 *$ \\
\hline & Tmax & $0.95 * *$ & $0.98 * *$ & $0.97 * *$ & 0.47 \\
\hline & VPD & $0.95 * *$ & $0.98 * *$ & $0.96 * *$ & -0.55 \\
\hline & ET & $0.95 * *$ & $0.98 * *$ & $0.98 * *$ & 0.46 \\
\hline & $\mathrm{RF}$ & -0.58 & $-0.85^{*}$ & $-0.79 *$ & -0.74 \\
\hline \multirow{5}{*}{$\begin{array}{l}\text { Branch } \\
\text { intiation }\end{array}$} & Tmin & $0.79 *$ & $0.93 * *$ & $0.93 * *$ & 0.72 \\
\hline & Tmax & -0.68 & -0.54 & -0.31 & 0.19 \\
\hline & VPD & $0.91 * *$ & $0.93 * *$ & $0.89 * *$ & -0.03 \\
\hline & ET & -0.61 & -0.38 & -0.20 & 0.30 \\
\hline & $\mathrm{RF}$ & 0.47 & $0.94 * *$ & $0.95 * *$ & 0.52 \\
\hline \multirow{5}{*}{$\begin{array}{c}\text { Ovary } \\
\text { development }\end{array}$} & Tmin & 0.38 & -0.10 & -0.04 & -0.58 \\
\hline & Tmax & $0.92 * *$ & $0.99 * *$ & $0.99 * *$ & 0.49 \\
\hline & VPD & $0.91 * *$ & $0.93 * *$ & $0.89 * *$ & -0.03 \\
\hline & ET & $0.94 * *$ & $0.98 * *$ & $0.99 * *$ & 0.50 \\
\hline & $\mathrm{RF}$ & -0.31 & -0.75 & -0.54 & $-0.78 *$ \\
\hline \multirow{5}{*}{$\begin{array}{c}\text { Spadix } \\
\text { emergence }\end{array}$} & Tmin & 0.60 & $0.90 * *$ & $0.85^{*}$ & 0.73 \\
\hline & $\operatorname{Tmax}$ & $-0.82 *$ & -0.50 & -0.65 & 0.14 \\
\hline & VPD & $-0.84^{*}$ & -0.74 & -0.41 & -0.15 \\
\hline & ET & $-0.76^{*}$ & -0.44 & -0.57 & 0.25 \\
\hline & $\mathrm{RF}$ & $0.83^{*}$ & $0.92 * *$ & $0.92 * *$ & 0.66 \\
\hline \multirow{5}{*}{$\begin{array}{c}\text { Button } \\
\text { development }\end{array}$} & Tmin & $0.99 * *$ & $0.84 *$ & 0.58 & 0.05 \\
\hline & Tmax & 0.23 & 0.34 & 0.69 & 0.58 \\
\hline & VPD & 0.11 & 0.46 & 0.67 & 0.57 \\
\hline & ET & 0.36 & 0.37 & $0.84 *$ & 0.55 \\
\hline & $\mathrm{RF}$ & 0.18 & 0.43 & $-0.96 * *$ & 0.12 \\
\hline
\end{tabular}

* significant at $0.05 * *$ significant at 0.01

Table.5 Linear regression model of nut yield for Chnaraypatna

\begin{tabular}{|c|c|c|c|c|c|}
\hline \multirow{2}{*}{ Model } & \multicolumn{2}{|c|}{$\begin{array}{c}\text { Unstandardized } \\
\text { Coefficients }\end{array}$} & $\begin{array}{c}\text { Standardize } \\
\mathrm{d} \\
\text { Coefficients }\end{array}$ & \multirow{2}{*}{ Sig. } & \\
\cline { 2 - 5 } & $\mathrm{B}$ & Std. Error & Beta & & \\
\hline Constant & -610.09 & 45.66 & -- & -13.38 & 0.00 \\
\hline $\mathrm{T}_{\text {max_primordium }}$ & 15.73 & 2.16 & 0.77 & 7.28 & 0.00 \\
\hline $\mathrm{T}_{\text {max_ovary development }}$ & -3.39 & 0.41 & -0.71 & -8.24 & 0.00 \\
\hline $\mathrm{T}_{\text {min_button stage }}$ & 7.58 & 0.93 & 0.84 & 8.13 & 0.00 \\
\hline $\mathrm{T}_{\text {max_button stage }}$ & 4.35 & 0.71 & 0.77 & 6.10 & 0.00 \\
\hline Dependent Variable: Nut_yield & & & & \\
\hline
\end{tabular}



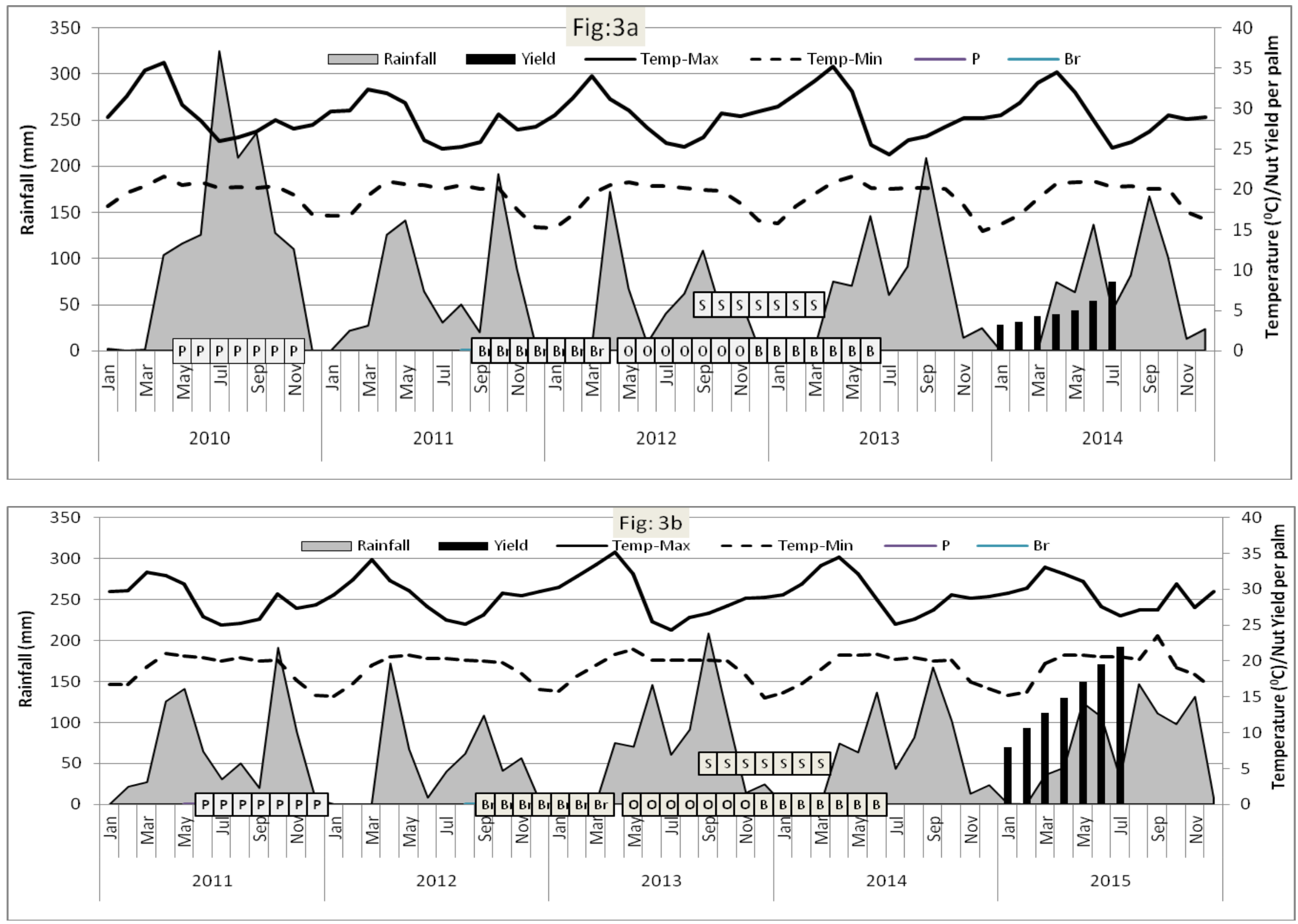

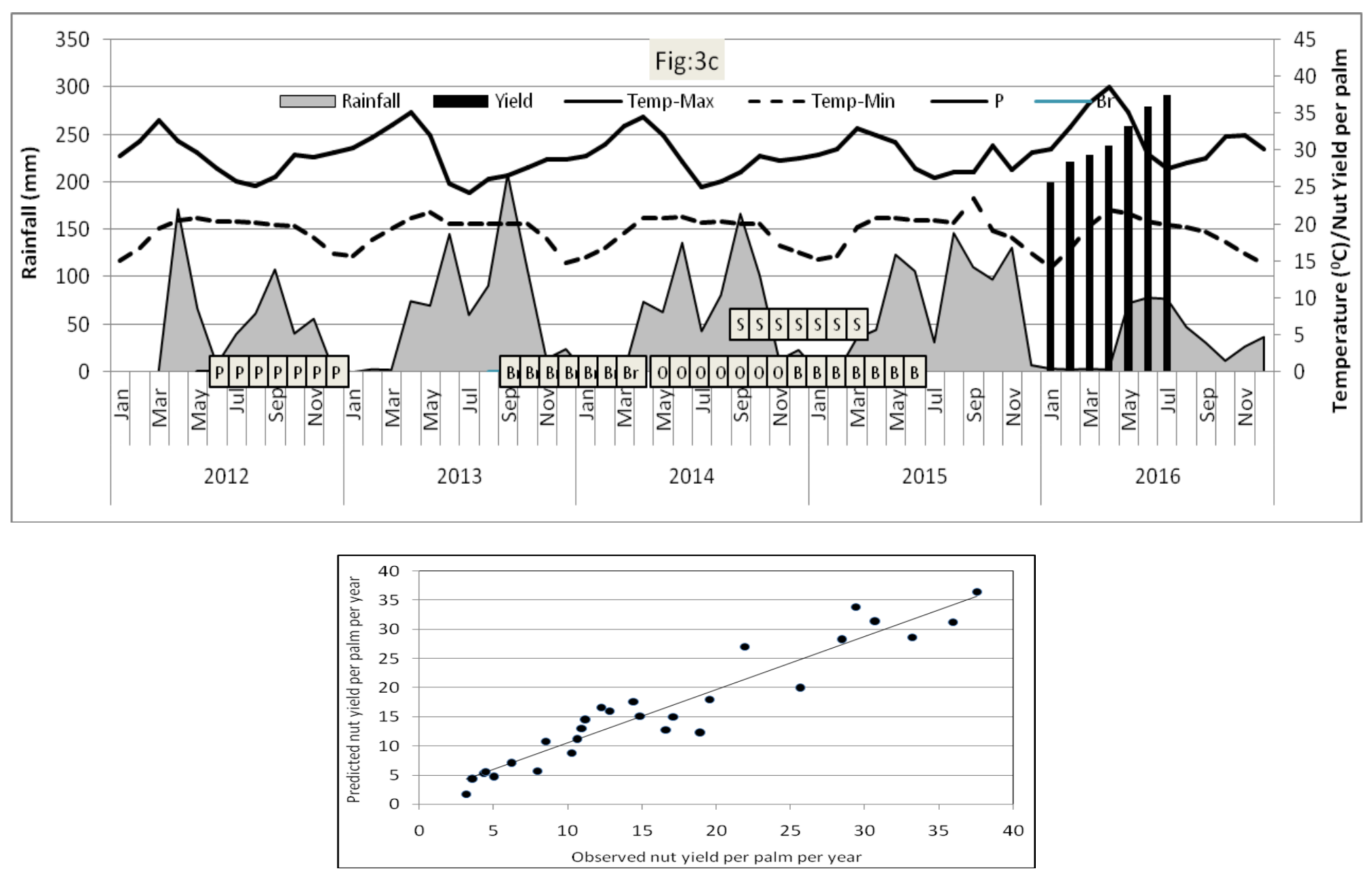

Fig.4 Scatter plot of observed and predicted nut yield 


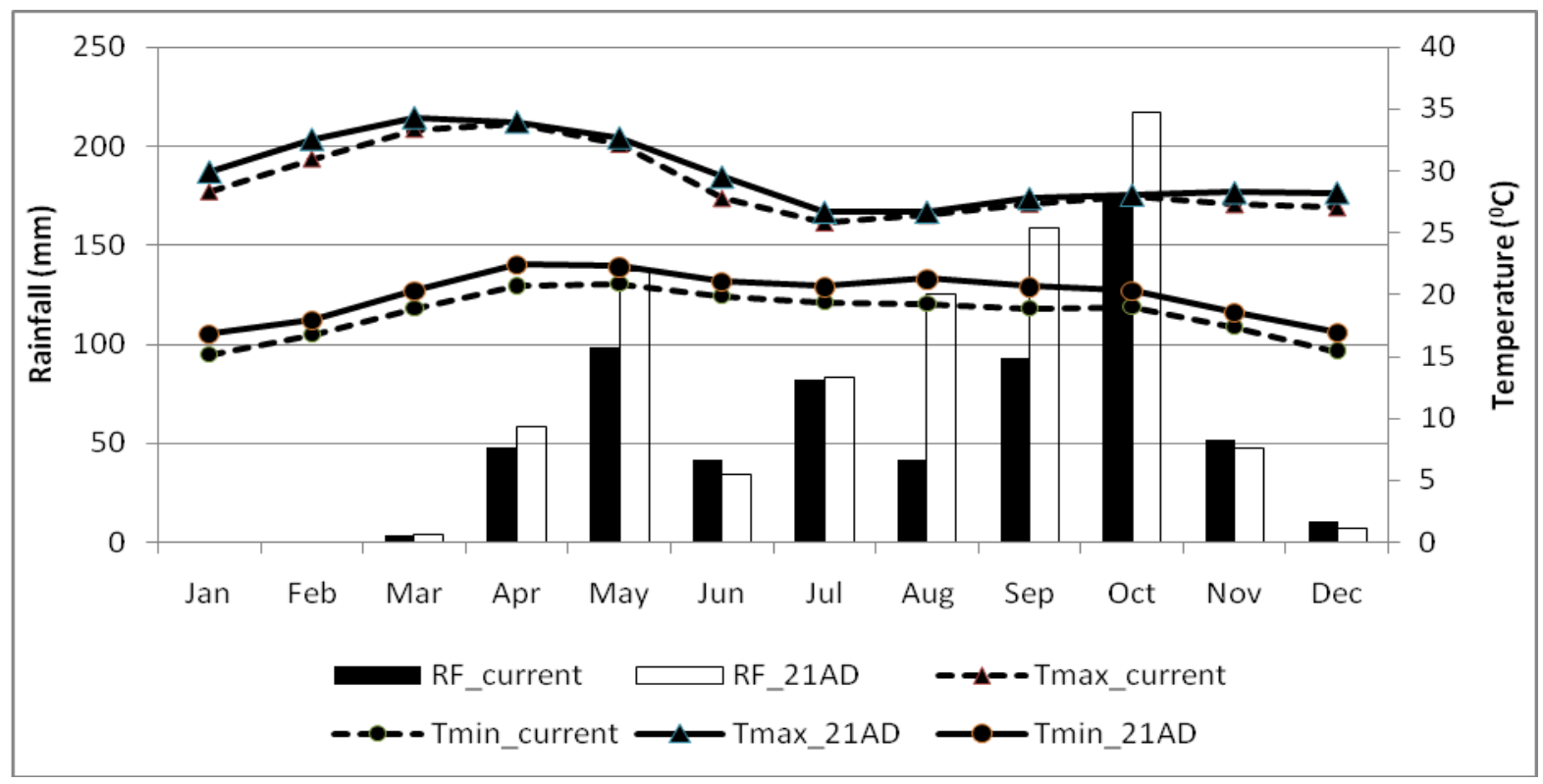

Fig.5 Current and future climate of Chanrayapatna

\section{Yield model}

Using the climatic variables as independent factor and nut yield per palm per month as dependent factor, a simple linear regression model was developed to predict nut yield. Details of simple weather based linear regression model are given in Table 5. According to model, maximum temperature during primordium initiation, ovary development and button stage and minimum temperature during button stage showed significant contribution to the model.

Actual and estimated monthly nut yield per palm using the above equations is illustrated in Figure 4. The results indicated that the actual and estimated values were in good agreement $\left(\mathrm{R}^{2}=0.91\right)$. In Chanrayapatna, rainfall did not contribute significantly in the prediction model as the holdings are being irrigated with bore well water as well as canal water.

\section{Climate change}

The long term (1950 to 2000) average rainfall of Chanrayapatna taluk of Hassan district
$646.1 \mathrm{~mm}$ with peak rainfall during September/October months (Fig. 5). Southwest monsoon rainfall account for 55 per cent of annual rainfall whereas northeast monsoon accounts for 37 percent.

Long term average maximum and minimum temperature is 29.4 and $18.7^{\circ} \mathrm{C}$ respectively. During March/April months maximum temperature reaches high. Annual maximum temperature of Chanrayapatna likely to be $29.9^{0} \mathrm{C}$ by 2100 as against the average of $28.98^{\circ} \mathrm{C}$ indicating the increase by $1.0^{\circ} \mathrm{C}$ over a century. Increase in maximum temperature was seen mainly during winter and monsoon period only. Minimum temperature also showed increasing trend and is likely to be $19.9^{\circ} \mathrm{C}$ by 2100 as against $18.5^{\circ} \mathrm{C}$ indicating a increase by $1.4^{0} \mathrm{C}$ over a century. Unlike maximum temperature, minimum temperature showed increase over average in all the months. This narrowing of difference between maximum and minimum temperature will increase the VPD resulting in increase of evaporative demand. Annual rainfall of Chanrayapatna is likely to be $874.3 \mathrm{~mm}$ by 2100 indicating the increase over average by $228.2 \mathrm{~mm}$. This increase is seen mainly in post 
monsoon period particularly August to October months and to some extent during May month. However rainfall is declining during November and December resulting in extension of dry period. Rainfall may increase but distribution may not be equal thus necessitating the need for on-site rainwater harvesting and conservation. Maximum and minimum temperature, rainfall and VPD are showing significant correlation with different nut development stages particularly primordium and ovary development stages, so future increase in maximum and minimum temperature is going to affect the nut yield.

From the present study it can be concluded that coconut yield at Chanrayapatna is significantly influenced by weather during the different nut development stages spread over 32 months before opening of inflorescence. Year to year variation was mainly due to weather particularly rainfall during the nut development stages mainly primordium initiation, ovary development and nut development stages. Weather based simple linear regression model consisting of maximum and minimum temperature during primordium development, ovary and button stage was developed and was in good agreement with observed nut yield. Future climate of Chanrayapatna showed increase in annual rainfall mainly during September and October but decline during November/ December resulting in increase in dry spell. $\mathrm{T}_{\max }$ as well $\mathrm{T}_{\min }$ also showed increase by 1$1.4^{0} \mathrm{C}$ which may increase the evaporative demand resulting in moisture stress. This stresses the importance of rain water harvesting to take advantage of increased rainfall under future climatic condition.

\section{Acknowledgement}

Authors acknowledge the Coconut Development Board, Regional Office, Hulimavu, Bengaluru for providing financial support in conducting coconut yield estimation survey in Channryapatna taluk of Hassan, district Karnataka during 2013 to 2017.

\section{References}

Abeywardena, V. 1968. Forecasting coconut crops using rainfall data-a preliminary study. Ceylon Coconut. Q. 19: 161-176.

DIVA GIS, 2018. http://www.divagis.org/climate (Accessed on 15-092018)

Kumar, S.N., Rajagopal, V, Thomas, S., Cherian, V.K., Narayan, R., Ananda, K.S., Nagwekar, D.D., Hanumanthappa, M., Vincent, C. and Srinivasalu, B. 2007. Variation in nut yield of coconut and dry spell in different agro-climatic zones of India. Indian Journal of Horticulture 64(3): 309-313.

Krishnakumar, K.N., 2011. Coconut Phenology and Yield Response to Climate Variability and Change, $P h D$ Thesis, Department of Atmospheric Sciences, Cochin University of Science And Technology Kochi, India, pp.241.

KSNDMC, 2018. Karnataka State Natural Disaster and Management Cell, Bengaluru. (https://www.ksndmc.org/)

Nambiar, M.C., Sreedharan, A. and Sankar, N. 1969. Preliminary observation on growth and likely effect of seasons on nut development in coconut. Indian $J$. Agric. Sci. 39: 455-461.

Peiris, T. S. G., Hansen, J.W. and Zubair, L. 2008. Use of seasonal climate information to predict coconut production in Sri Lanka. Int. journal of climatol. 28: 103-110.

Peiris, T. S. G and Thattil, R.O. 1998. The study of climate effects on nut yield of coconut using Parsimonious models. Experimental Agriculture, 34:189-206.

Peiris, T.S.G., Thattl, R.O. and Mahindapala, R. 1995. An analysis of the effect of 
climate and weather on coconut (Cocos nucifera). Expl. Agric. 31:451-463.

Rajagopal, V., Shivasankar, S. and Mathew, J. 1996. Impact of dry spells on the ontogeny of coconut fruits and its relation to yield. Plantation Res.Dev. 3: 251-255

Rao, G.S.L.H.V.P. 1988. Agrometeorology of coconut. Six Decades of Coconut Research. (eds. Aravindakshan, M., Nair, R.R. and Wahid, P.A.). Kerala
Agricultural University, Thrissur, pp. 81-93

Rao, G.S.L.H.V.P., Gopakumar, C.S. and Sebastian, S. 1993. Effect of drought on nut yield in different yield groups of west coast tall. J. plantation crops 21:25-28

Reynolds, S. G. 1979. A simple method for prediction of coconut yields. Philippines Journal of Coconut Studies 4 (3): 41-44.

\section{How to cite this article:}

Shripad Vishweshwar, Shankar Meti, B.V. Champa and Nagaraja, M. 2019. Climate Based Coconut Yield Analysis in Chanrayapatna Taluk of Hassan District of Karnataka, India. Int.J.Curr.Microbiol.App.Sci. 8(07): 2867-2877. doi: https://doi.org/10.20546/ijcmas.2019.807.357 